\title{
Dependence of Thermal and Electrical Conductivities of Actinide-Zirconium-Hydride Composite Materials on Hydrogen Concentration
}

\author{
B. Tsuchiya ${ }^{1}$, K. Konashi ${ }^{2}$ and M. Yamawaki ${ }^{3}$ \\ ${ }^{1}$ Department of General Education, Faculty of Science and Technology, Meijo University, \\ 1-501, Shiogamaguchi, Tempaku-ku, Nagoya 468-8502, \\ 2International Research Center for Nuclear Materials Science, \\ Institute for Materials Research, Tohoku University, \\ Oarai-machi, Ibaraki-ken 311-1313, \\ ${ }^{3}$ Department of Applied Physics, Graduate School of Engineering, Tokai University, \\ 1117, Kitakaname, Hiratsuka, Kanagawa 259-1292,
}

Japan

\section{Introduction}

High-level radioactive waste generated by the reprocessing of spent nuclear fuel from nuclear reactors includes long-lived radioactive nuclides. The current method for the disposal of such waste involves the vitrifying the waste under rigid control, storing it in monitored areas until the radiation decays to permissible levels, and then disposing it underground. Many types of transmutation methods have been studied to reduce the need for geological disposal. Recently, a transmutation method has been proposed for actinide radioactive waste; this method involves the use of hydride irradiation targets, which are loaded in the form of pellets into the core of fast breeder reactors containing mixed-oxide fuel (Yamamoto et al., 1997), (Yamawaki et al., 1998), and (Konashi et al., 2001). The irradiation hydride targets are composite materials, composed of titanium, zirconium, and hafnium hydrides, which contain hydrogen storage metals, and actinide elements such as ${ }^{237} \mathrm{~Np}$, ${ }^{241} \mathrm{Am}$, and ${ }^{243} \mathrm{Am}$. The hydrides in the irradiation targets act as neutron moderators to provide a high flux of the thermal neutron. During irradiation, a temperature gradient occurs between the center and edge of the targets, and the distribution of the hydrogen concentration changes with the hydrogen diffusion (Huang et al., 2000). In the design of irradiation hydride targets, it is extremely important to investigate the changes in the mechanical, thermal, and electrical properties of the hydrides including their various hydrogen concentrations and to understand the basic heat transfer processes. Thermal conductivity is the most important physical property.

In the present study, the effects of the hydrogen content on the electrical and thermal properties of metal-hydride composite materials such as uranium-zirconium hydrides (45 wt $\% \mathrm{U}-\mathrm{ZrH}_{\mathrm{x}} ; x=1.60$ and 1.90$)$ and uranium-thorium-zirconium hydrides $\left(\mathrm{UTh}_{4} \mathrm{Zr}_{10} \mathrm{H}_{\mathrm{x}} ; x=\right.$ 
18-27) are investigated, and the heat conduction due to free electrons and that due to free phonons are discussed. From the results we can estimate the absolute values of the thermal conductivities for actinide-hydride composite materials including $\mathrm{Np}$ and Am. We also consider the correlation between the thermal transportation and the hydrogen content for the irradiation hydride targets since the hydrogen chemical potential of Th-hydride is close to those of $\mathrm{Np}$ - and Am-hydrides.

\section{Experiments}

Alloys with $45 \mathrm{wt} \% \mathrm{U}-\mathrm{Zr}$ and $\mathrm{UTh}_{4} \mathrm{Zr}_{10}$ were prepared by melting the constituent elements $-U$ and $\mathrm{Zr}$ with a purity of $99.9 \mathrm{wt} \%$ and Th with a purity of $99.99 \mathrm{wt} \%$-in vacuum in a high-frequency induction furnace, which was manufactured by Mitsubishi Materials Corporation. The composition of the UTh $\mathrm{Zr}_{10}$ alloy was selected so as to ensure solid solution formation at high temperatures and more amount of absorbed hydrogen than any other U-Th-Zr alloy (Yamamoto et al., 1997) and (Yamawaki et al., 1998). The microstructure of the $\mathrm{UTh}_{4} \mathrm{Zr}_{10}$ alloy mixing $\alpha-\mathrm{Th}_{\text {with }} \beta-\mathrm{UZr}_{2+x}$ phases, as shown in Fig. 2(a), was observed using scanning electron microscopy (SEM) and X-ray diffraction (XRD). The hydrogenation of $45 \mathrm{wt} \% \mathrm{U}-\mathrm{Zr}$ and $\mathrm{UTh}_{4} \mathrm{Zr}_{10}$ alloys was carried out using Sieverts' apparatus, supplied by Mitsubishi Materials Corporation (Tsuchiya et al., 2000). The $45 \mathrm{wt} \%$ $\mathrm{U}-\mathrm{Zr}$ and $\mathrm{UTh} \mathrm{ZZ}_{10}$ alloys, mounted into a quartz tube evacuated under a pressure of $1.3 \times$ $10^{-4} \mathrm{~Pa}$, were heated at $1173 \mathrm{~K}$ for $3.5 \mathrm{~h}$ to remove a small amount of residual hydrogen, absorbed into the alloys during the melting and quenching of the constituent elements. The alloys were then heated at temperatures ranging from 673 to $1173 \mathrm{~K}$ and exposed to pure protium gas in the quartz tube at pressures ranging from $1.0 \times 10^{3}$ to $1.0 \times 10^{5} \mathrm{~Pa}$, where the temperature and pressure values were measured using a thermocouple and a baratoron, respectively. When equilibrium for the hydrogenation was achieved, the protium gas was removed from the quartz tube and the annealing temperature was then gradually reduced to room temperature, with the sample still in the tube.

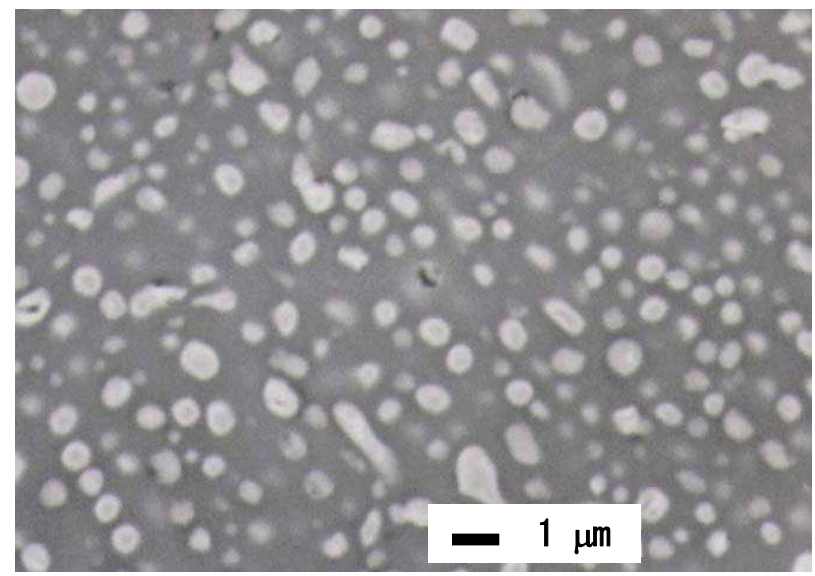

Fig. 1. SEM (BEI: backscattered electron image) micrograph of $45 \mathrm{wt} \% \mathrm{U}-\mathrm{ZrH}_{1.60}$, composed of $\alpha-\mathrm{U}$ (white area) and $\delta$ - $\mathrm{ZrH}_{1.60}$ (dark area) phases 
(a)

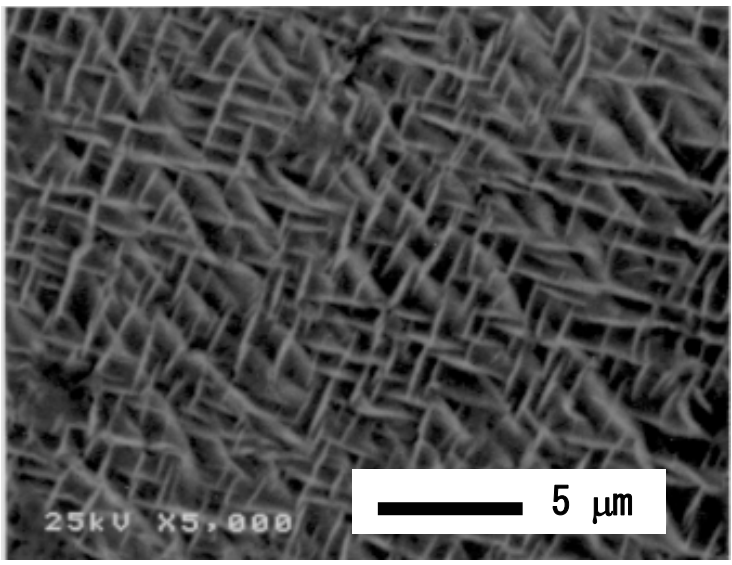

(b)

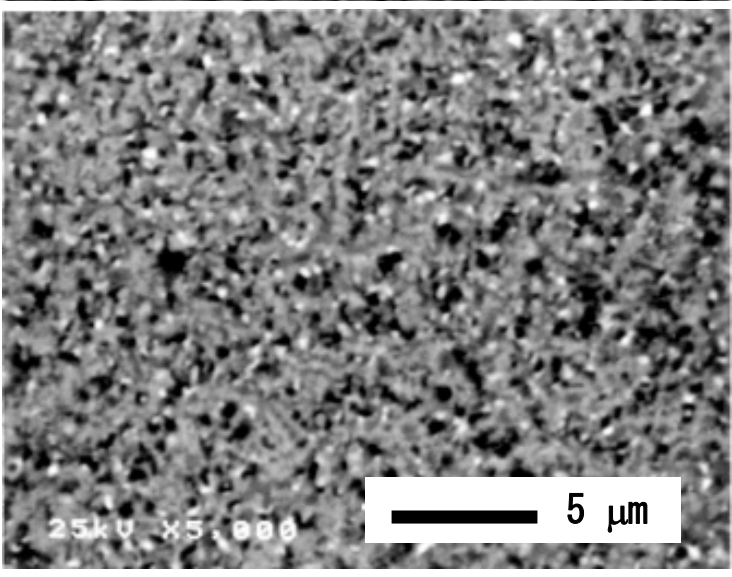

(c)

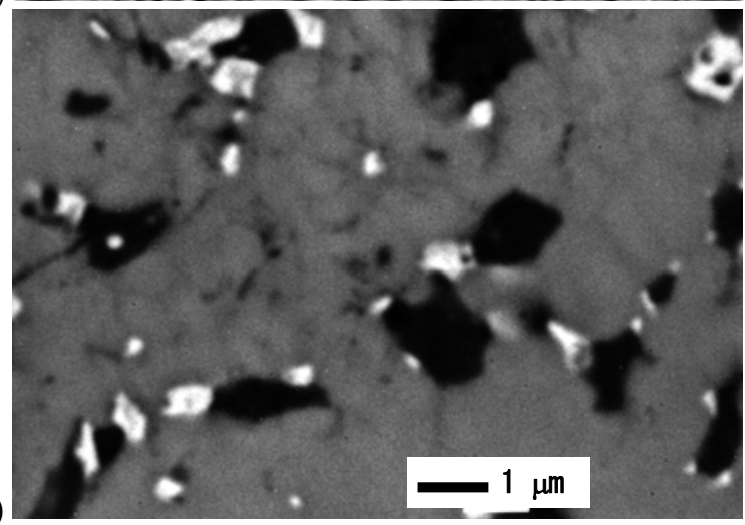

Fig. 2. SEM (BEI: backscattered electron image) micrographs of (a) $U \mathrm{Uh}_{4} \mathrm{Zr}_{10}$ alloy, which is composed of $\alpha$-Th (white area) and $\beta-\mathrm{UZr}_{2+x}$ (black area) phases, (b) and (c) $\mathrm{UTh}_{4} \mathrm{Zr}_{10} \mathrm{H}_{24}$ which is composed of $\alpha-\mathrm{U}$ (white area), $\mathrm{ThZr}_{2} \mathrm{H}_{5.59}$ (gray area), and $\mathrm{ZrH}_{1.86}$ (black area) phases 
The compositions of the $45 \mathrm{wt} \% \mathrm{U}-\mathrm{Zr}$ and $\mathrm{UTh}_{4} \mathrm{Zr}_{10}$ hydrides were measured based on the hydrogen pressure changes at equilibrium and the mass gains before and after hydrogenation. The fabricated products were $45 \mathrm{wt} \% \mathrm{U}-\mathrm{ZrH}_{\mathrm{x}}(x=1.60$ and 1.90) and $\mathrm{UTh}_{4} \mathrm{Zr}_{10} \mathrm{H}_{\mathrm{x}}(x=18-27)$. The surface morphology and crystalline structure of these two hydride composite materials were extensively examined using SEM and XRD. Figure 1 shows an SEM (BEI: backscattered electron image) micrograph of $45 \mathrm{wt} \% \mathrm{U}-\mathrm{ZrH}_{1.60}$. It reveals that the $\mathrm{U}$ phase of approximately $1.0 \mu \mathrm{m}$ in diameter is dispersed in the bulk of the $\mathrm{ZrH}_{1.60}$ phase; this is indicative of a composite material mixing an actinide element with a hydride. The morphology of $45 \mathrm{wt} \% \mathrm{U}-\mathrm{ZrH}_{1.90}$ is almost the same as that of $45 \mathrm{wt} \%$ $\mathrm{U}-\mathrm{ZrH}_{1.60}$. The structures of $\mathrm{U}, \mathrm{ZrH}_{1.60}$, and $\mathrm{ZrH}_{1.90}$ are orthorhombic ( $\alpha$-phase), facecentered cubic ( $\delta$-phase), and face-centered tetragonal ( $\varepsilon$-phase), respectively (Tsuchiya et al., 2001).

BEI-SEM micrographs with magnifying powers of 5000 and 10000 for $\mathrm{UTh}_{4} \mathrm{Zr}_{10} \mathrm{H}_{24}$ are shown in Figs. 2(b) and (c), respectively. The $\alpha-U$ (white area) and $\mathrm{ZrH}_{1.86}$ (black area) phases of approximately $1.0 \mu \mathrm{m}$ in diameter are dispersed in the bulk of the $\mathrm{ThZ}_{2} \mathrm{H}_{5.59}$ (gray area) phase; this is indicative of a composite material mixing an actinide element with two kinds of hydrides. The values of $x$ in $\mathrm{ThZr}_{2} \mathrm{H}_{\mathrm{x}}$ and $\varepsilon-\mathrm{ZrH}_{\mathrm{x}}$ were estimated based on the relationship between the measured XRD data and published data (Nakata et al., 1966), (Yamamoto et al., 1997), and (Tsuchiya et al., 2002). The other hydrides of $\mathrm{UTh}_{4} \mathrm{Zr}_{10} \mathrm{H}_{\mathrm{x}}$ were determined to be $\mathrm{ThZr}_{2} \mathrm{H}_{3.30}$ and $\delta-\mathrm{ZrH}_{1.69}\left(\mathrm{UTh}_{4} \mathrm{Zr}_{10} \mathrm{H}_{18}\right), \mathrm{ThZr}_{2} \mathrm{H}_{4.17}$ and $\varepsilon-\mathrm{ZrH}_{1.74}\left(\mathrm{UTh}_{4} \mathrm{Zr}_{10} \mathrm{H}_{20}\right), \mathrm{ThZr}_{2} \mathrm{H}_{5.59}$ and $\varepsilon-\mathrm{ZrH}_{1.83}\left(\mathrm{UTh}_{4} \mathrm{Zr}_{10} \mathrm{H}_{23}\right), \mathrm{ThZr}_{2} \mathrm{H}_{5.79}$ and $\varepsilon-\mathrm{ZrH}_{1.87}$ $\left(\mathrm{UTh}_{4} \mathrm{Zr}_{10} \mathrm{H}_{26}\right)$, and $\mathrm{ThZr}_{2} \mathrm{H}_{5.94}$ and $\varepsilon-\mathrm{ZrH}_{1.90}\left(\mathrm{UTh}_{4} \mathrm{Zr}_{10} \mathrm{H}_{27}\right)$, respectively. Therefore, the hydrides of $\mathrm{UTh}_{4} \mathrm{Zr}_{10} \mathrm{H}_{\mathrm{x}}(x=18-27)$ are mainly three-phase composite materials, composed of $\alpha$-U, $\delta$-phase $\mathrm{ZrH}_{\mathrm{x}}(1.5 \leq x<1.7)$ or $\varepsilon$-phase $\mathrm{ZrH}_{\mathrm{x}}(1.7 \leq x \leq 2.0)$, and $\mathrm{ThZr}_{2} \mathrm{H}_{\mathrm{x}}$ $(4.0<x<6.3)$, although there are small quantities of residual $\mathrm{Th}$, Th hydrides, and oxides such as $\mathrm{ThO}_{2}$ and $\mathrm{ZrO}_{2}$.

Figures 3(a) and (b) show the hydrogen release from $45 \mathrm{wt} \% \mathrm{U}-\mathrm{ZrH}_{1.60}, \mathrm{U}-\mathrm{ZrH}_{1.90}, \mathrm{ZrH}_{1.60}$, $\mathrm{ZrH}_{1.90}, \mathrm{UTh}_{4} \mathrm{Zr}_{10} \mathrm{H}_{20}, \mathrm{UTh}_{4} \mathrm{Zr}_{10} \mathrm{H}_{24}$, and $\mathrm{UTh}_{4} \mathrm{Zr}_{10} \mathrm{H}_{27}$ by isochronal annealing for $10 \mathrm{~min}$ at temperatures of 298-973 K. In Fig. 3(a) it is important to note that the decomposition temperature of $823 \mathrm{~K}$ for $\mathrm{U}-\mathrm{ZrH}_{1.60}$ is the same as that for $\mathrm{ZrH}_{1.60}$, while the temperature of $773 \mathrm{~K}$ for $\mathrm{U}-\mathrm{ZrH}_{1.90}$ is higher than that for $\mathrm{ZrH}_{1.90}$. The decomposition temperatures of $\mathrm{UTh}_{4} \mathrm{Zr}_{10} \mathrm{H}_{20}, \mathrm{UTh}_{4} \mathrm{Zr}_{10} \mathrm{H}_{24}$, and $\mathrm{UTh}_{4} \mathrm{Zr}_{10} \mathrm{H}_{27}$ are approximately 823, 723, and $673 \mathrm{~K}$, respectively, as shown in Fig. 3(b). There are two types of stages in the hydrogen molecular re-emission process. The first and second stages of the re-emission are due to hydrogen release from the $\mathrm{ThZr}_{2} \mathrm{H}_{\mathrm{x}}$ and $\mathrm{ZrH}_{\mathrm{x}}$ phases, respectively.

To avoid the reduction of the hydrogen concentration by hydrogen molecular re-emission, special specimen containers, made of sapphire, were used for the thermal diffusivity measurements with a laser flash method (Tsuchiya et al., 2002). The heating temperatures were successful in elevating to $900 \mathrm{~K}\left(\mathrm{U}-\mathrm{ZrH}_{1.60}, \mathrm{UTh}_{4} \mathrm{Zr}_{10} \mathrm{H}_{18}\right.$, and $\left.\mathrm{UTh}_{4} \mathrm{Zr}_{10} \mathrm{H}_{20}\right), 840 \mathrm{~K}$ $\left(\mathrm{U}-\mathrm{ZrH}_{1.90}\right), 800 \mathrm{~K}\left(\mathrm{UTh}_{4} \mathrm{Zr}_{10} \mathrm{H}_{23}\right.$ and $\left.\mathrm{UTh}_{4} \mathrm{Zr}_{10} \mathrm{H}_{24}\right), 750 \mathrm{~K}\left(\mathrm{UTh}_{4} \mathrm{Zr}_{10} \mathrm{H}_{24}\right.$ and $\left.\mathrm{UTh}_{4} \mathrm{Zr}_{10} \mathrm{H}_{26}\right)$, and $700 \mathrm{~K}\left(\mathrm{UTh}_{4} \mathrm{Zr}_{10} \mathrm{H}_{27}\right)$ during the thermal diffusivity measurements. In addition, an electrical resistivity measurement was carried out from room temperature to $700-800 \mathrm{~K}$ for each hydride using a four-contact method with a direct current (DC) of $350 \mathrm{~mA}$, to clarify the heat conduction due to free electrons. 


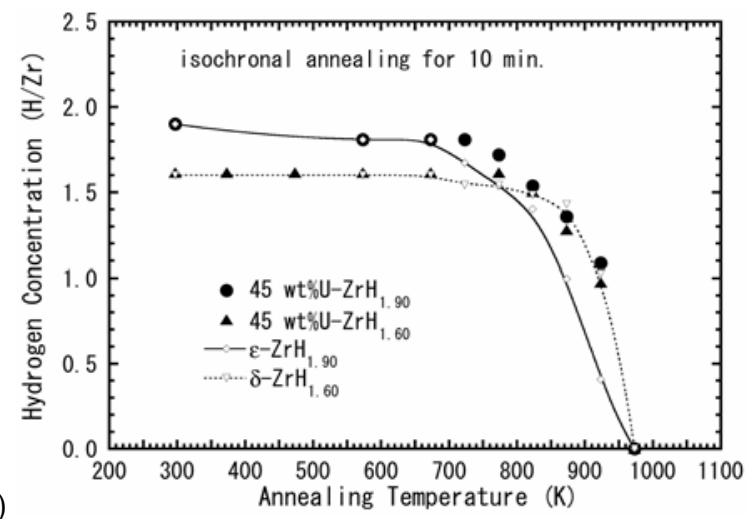

(a)

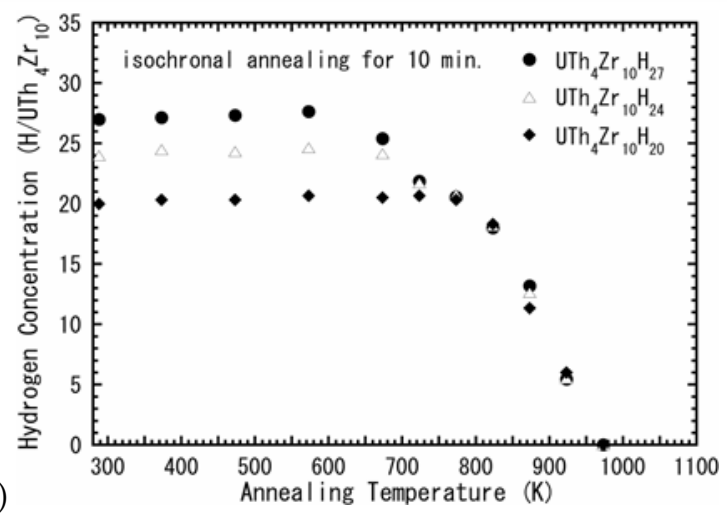

Fig. 3. Changes in hydrogen concentrations in (a) $\mathrm{U}-\mathrm{ZrH}_{1.60}, \mathrm{U}-\mathrm{ZrH}_{1.90}, \mathrm{ZrH}_{1.60}$, and $\mathrm{ZrH}_{1.90}$ and (b) $\mathrm{UTh}_{4} \mathrm{Zr}_{10} \mathrm{H}_{20}, \mathrm{UTh}_{4} \mathrm{Zr}_{10} \mathrm{H}_{24}$, and $\mathrm{UTh}_{4} \mathrm{Zr}_{10} \mathrm{H}_{27}$ after isochronal annealing at different temperatures for $10 \mathrm{~min}$

\section{Results and discussion}

Figures $4(\mathrm{a})$ and $(\mathrm{b})$ show the thermal diffusivities of $45 \mathrm{wt} \% \mathrm{U}-\mathrm{ZrH}_{1.60}, 45 \mathrm{wt} \% \mathrm{U}-\mathrm{ZrH}_{1.90}$, $\mathrm{UTh}_{4} \mathrm{Zr}_{10} \mathrm{H}_{18}, \quad \mathrm{UTh}_{4} \mathrm{Zr}_{10} \mathrm{H}_{20}, \quad \mathrm{UTh}_{4} \mathrm{Zr}_{10} \mathrm{H}_{23}, \quad \mathrm{UTh}_{4} \mathrm{Zr}_{10} \mathrm{H}_{24}, \mathrm{UTh}_{4} \mathrm{Zr}_{10} \mathrm{H}_{26}$, and $\mathrm{UTh}_{4} \mathrm{Zr}_{10} \mathrm{H}_{27}$, measured while increasing (solid marks) and decreasing (open marks) the heating temperature. The agreement between the values on heating and cooling indicates that there is no hydrogen release from the hydrides during the thermal diffusivity measurements. The thermal diffusivities for $\mathrm{U}-\mathrm{ZrH}_{1.60}$ and $\mathrm{U}-\mathrm{ZrH}_{1.90}$ increased with increasing hydrogen concentration and with decreasing temperature. The temperature dependence of the thermal diffusivities for $\mathrm{U}-\mathrm{ZrH}_{1.60}$ and $\mathrm{U}-\mathrm{ZrH}_{1.90}$ is similar to that for $\mathrm{ZrH}_{1.60}$ and $\mathrm{ZrH}_{1.90}$ (Tsuchiya et al., 2002), although the absolute values are different, as shown in Fig. 4(a). This is because the thermal diffusivity of $U$ is nearly constant in the temperature range up to 900 K (Takahashi et al., 1988). The present experimental values are approximately 1.5 times those of $10 \mathrm{wt} \% \mathrm{U}-\mathrm{ZrH}_{\mathrm{x}}$ (Nakata et al., 1966), depending on the amount of doped-U.

On the other hand, the thermal diffusivities of $\mathrm{UTh}_{4} \mathrm{Zr}_{10} \mathrm{H}_{23}, \mathrm{UTh}_{4} \mathrm{Zr}_{10} \mathrm{H}_{24}, \mathrm{UTh}_{4} \mathrm{Zr}_{10} \mathrm{H}_{26}$, and $\mathrm{UTh}_{4} \mathrm{Zr}_{10} \mathrm{H}_{27}$ decreased with increasing temperature, while those of $\mathrm{UTh}_{4} \mathrm{Zr}_{10} \mathrm{H}_{18}$ and 
$\mathrm{UTh}_{4} \mathrm{Zr}_{10} \mathrm{H}_{20}$ increased gradually up to a temperature of $940 \mathrm{~K}$, as shown in Fig. 4(b). It is interesting to note that the thermal diffusivities at $640 \mathrm{~K}$ for $\mathrm{UTh}_{4} \mathrm{Zr}_{10} \mathrm{H}_{18-27}$ are equal.

(a)
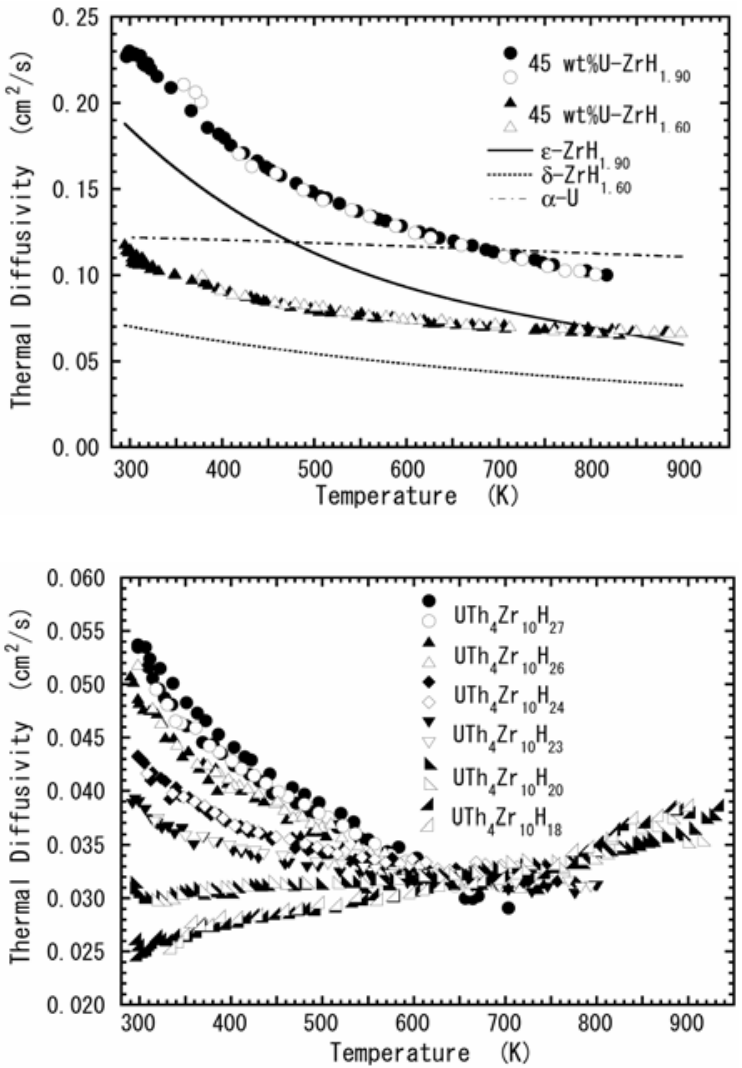

Fig. 4. Temperature dependence of the thermal diffusivities for (a) $\mathrm{U}-\mathrm{ZrH}_{\mathrm{x}}(x=1.60$ and 1.90), $\mathrm{ZrH}_{\mathrm{x}}\left(x=1.60\right.$ and 1.90), $\mathrm{U}$, and (b) $\mathrm{UTh}_{4} \mathrm{Zr}_{10} \mathrm{H}_{\mathrm{x}}(x=18,20,23,24,26$, and 27)

To clarify the electronic heat conduction for $\mathrm{U}-\mathrm{ZrH}_{\mathrm{x}}$ and $\mathrm{UTh}_{4} \mathrm{Zr}_{10} \mathrm{H}_{\mathrm{x}}$, the electrical resistivity was measured when heating to $700-800 \mathrm{~K}$ and cooling to room temperature. Figures 5(a) and (b) show the electrical resistivities of $45 \mathrm{wt} \% \mathrm{U}-\mathrm{ZrH}_{1.60}, 45 \mathrm{wt} \% \mathrm{U}-\mathrm{ZrH}_{1.90}$, $\mathrm{UTh}_{4} \mathrm{Zr}_{10} \mathrm{H}_{18}, \mathrm{UTh}_{4} \mathrm{Zr}_{10} \mathrm{H}_{20}, \mathrm{UTh}_{4} \mathrm{Zr}_{10} \mathrm{H}_{23}$, and $\mathrm{UTh}_{4} \mathrm{Zr}_{10} \mathrm{H}_{26}$ when heating (solid marks) and cooling (open marks). The electrical resistivities of $\mathrm{U}-\mathrm{ZrH}_{\mathrm{x}}$ increased as the temperature increased and the hydrogen concentration decreased, as shown in Fig. 5(a). In the case of U$\mathrm{ZrH}_{1.90}$, a slight distortion between the values obtained on heating and those obtained on cooling indicates a reduction in the hydrogen concentration, following hydrogen release from $\mathrm{ZrH}_{1.90}$. The hydrogen concentration dependence on the resistivity of $\mathrm{U}-\mathrm{ZrH}_{\mathrm{x}}$ strongly dominates that of $\mathrm{ZrH}_{x}$ (Bickel \& Berlincourt, 1970) and (Tsuchiya et al., 2002) and slightly dominates that of $U$ (Bell, 1954). The electron scattering due to hydrogen vacancy in the hydrides significantly affects the resistivity. The scattering of electrons due to optical phonons as well as acoustic phonons affects the resistivity behavior at higher temperature. 
The results for $\mathrm{UTh}_{4} \mathrm{Zr}_{10} \mathrm{H}_{\mathrm{x}}$ showed gradual decreases in the electrical resistivity with an increase in the hydrogen composition to approximately $690 \mathrm{~K}$, which was higher than the temperature $(640 \mathrm{~K})$ for the thermal diffusivity, and an increase above $690 \mathrm{~K}$, as shown in Fig. 5(b). The electron scattering due to hydrogen vacancies in both the $\mathrm{ZrH}_{\mathrm{x}}$ and $\mathrm{ThZr}_{2} \mathrm{H}_{\mathrm{x}}$ phases significantly reflects the temperature dependence of the electronic conduction for $\mathrm{UTh}_{4} \mathrm{Zr}_{10} \mathrm{H}_{\mathrm{x}}$. In particular, at higher temperatures the scattering of electrons due to optical phonons in the $\mathrm{ThZr}_{2} \mathrm{H}_{x}$ phase may essentially dominate the resistivity, although the resistivity of $\mathrm{ThZr}_{2} \mathrm{H}_{x}$ has not been measured yet.

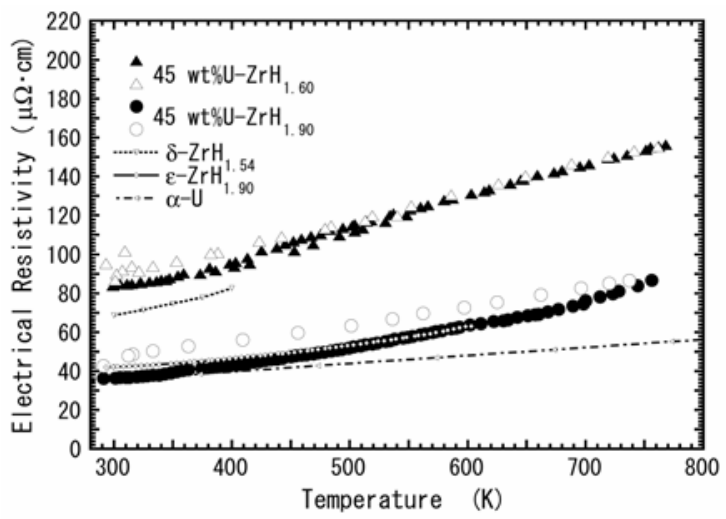

(a)

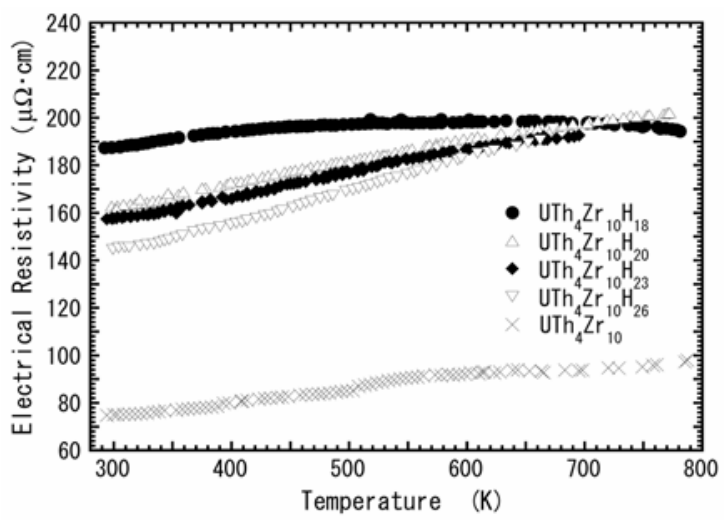

Fig. 5. Temperature dependence of electrical resistivities for (a) $\mathrm{U}-\mathrm{ZrH}_{\mathrm{x}}(x=1.60$ and 1.90), $\mathrm{ZrH}_{\mathrm{x}}\left(x=1.54\right.$ and 1.90), $\mathrm{U}$, and (b) $\mathrm{UTh}_{4} \mathrm{Zr}_{10} \mathrm{H}_{\mathrm{x}}(x=0,18,20,23$, and 26)

Figures 6 (a) and (b) show the thermal conductivities, $\lambda$, of $45 \mathrm{wt} \% \mathrm{U}-\mathrm{ZrH}_{1.60}$ and $45 \mathrm{wt} \% \mathrm{U}$ $\mathrm{ZrH}_{1.90}$, respectively, at temperatures up to $773 \mathrm{~K}$, which were calculated via $\lambda=\alpha \mathrm{C}_{\mathrm{p}} d$, where $\alpha, C_{\mathrm{p}}$, and $d$ represent the measured thermal diffusivity, the specific heat, and the density, respectively. The experimental values of $d$ for $\mathrm{U}-\mathrm{ZrH}_{1.60}$ and $\mathrm{U}-\mathrm{ZrH}_{1.90}$ were $d=$ 8.256 and $8.209 \mathrm{~g} / \mathrm{cm}^{3}$, respectively. The values of $C_{\mathrm{p}}$ for $\mathrm{U}-\mathrm{ZrH}_{1.60}$ and $\mathrm{U}-\mathrm{ZrH}_{1.90}$ were expressed by the following equations as functions of temperature, $T: C_{p}=0.120+4.72 \times 10^{-4}$ $T$ and $C_{p}=0.146+4.71 \times 10^{-4} T[\mathrm{~J} /(\mathrm{g} \cdot \mathrm{K})]$, respectively, taking into account the weight fractions of $U$ and $\mathrm{ZrH}_{x}$ and reported data on the specific heat of $\mathrm{U} ; C_{\mathrm{p}}=0.120 \mathrm{~J} /(\mathrm{g} \cdot \mathrm{K})$ and 
$\mathrm{ZrH}_{\mathrm{x}}(x=1.60-2.00) ; C_{\mathrm{p}}=\left[6.98 \times 10^{-2} \mathrm{~T}+\{34.4+14.8 \times(x-1.65)\}\right] / M_{\mathrm{ZrHx}}[\mathrm{J} /(\mathrm{g} \cdot \mathrm{K})]$, where $x$ and $M_{\mathrm{ZrHx}}$ are the composition of $\mathrm{H}$ in $\mathrm{ZrH}_{\mathrm{x}}$ and the molecular weight of $\mathrm{ZrH}_{\mathrm{x}}$ (Simnad, 1981). The temperature dependence of the thermal conductivity for $45 \mathrm{wt} \% \mathrm{U}-\mathrm{ZrH}_{1.60}$ was almost constant with increasing temperature, while that for $\mathrm{U}-\mathrm{ZrH}_{1.90}$ showed a gradual decrease. The conductivities of approximately $0.27 \mathrm{~W} /(\mathrm{cm} \cdot \mathrm{K})\left(45 \mathrm{wt} \% \mathrm{U}-\mathrm{ZrH}_{1.60}\right)$ and 0.43 $\mathrm{W} /(\mathrm{cm} \cdot \mathrm{K})\left(45 \mathrm{wt} \% \mathrm{U}-\mathrm{ZrH}_{1.90}\right)$ at a temperature of $700 \mathrm{~K}$ were higher than the reported value $(0.18 \mathrm{~W} /(\mathrm{cm} \cdot \mathrm{K}))$ for $10 \mathrm{wt} \% \mathrm{U}-\mathrm{ZrH}_{1.6}$ without temperature dependence; this value has been used for TRIGA reactors. The conductivity strongly depends on the quantities of absorbed hydrogen and doped-U.

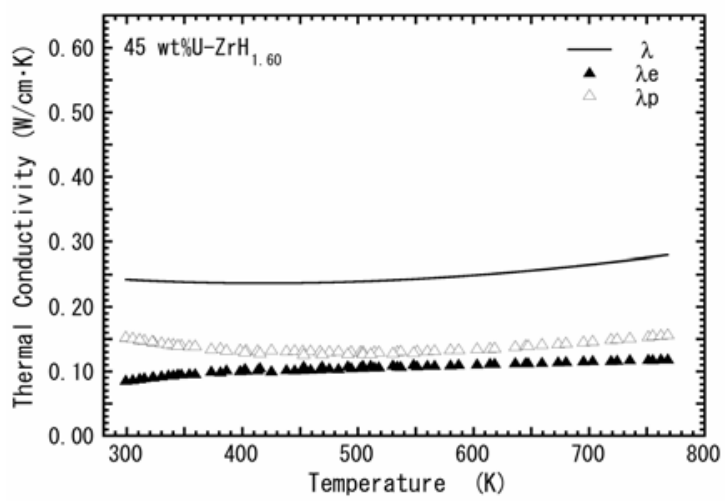

(a)

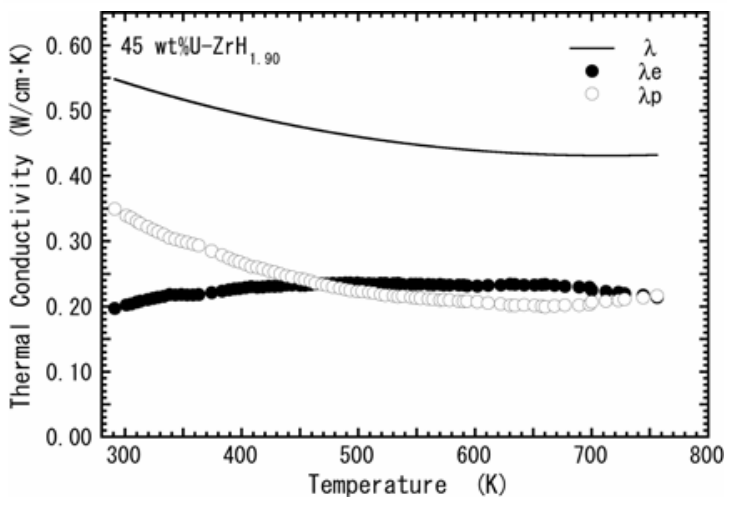

Fig. 6. Thermal conductivities, $\lambda$, of (a) $\mathrm{U}-\mathrm{ZrH}_{1.60}$ and (b) $\mathrm{U}-\mathrm{ZrH}_{1.90}$. $\lambda_{\mathrm{e}}$ and $\lambda_{\mathrm{p}}$ represent the thermal conductivity due to free electrons and that due to phonons, respectively

Figures 7 (a), (b), (c), and (d) show the thermal conductivities, $\lambda$, of $\mathrm{UTh}_{4} \mathrm{Zr}_{10} \mathrm{H}_{18}$, $\mathrm{UTh}_{4} \mathrm{Zr}_{10} \mathrm{H}_{20}, \mathrm{UTh}_{4} \mathrm{Zr}_{10} \mathrm{H}_{23}$, and $\mathrm{UTh}_{4} \mathrm{Zr}_{10} \mathrm{H}_{26}$, respectively, calculated using the equation given above. The density and specific heat values of $\mathrm{UTh}_{4} \mathrm{Zr}_{10} \mathrm{H}_{\mathrm{x}}(x=18-27)$ are expressed by considering the experimental results and the reported values of specific heat as follows: $d$ $=8.40-2.99 \times 10^{-2} x\left[\mathrm{~g} / \mathrm{cm}^{3}\right]$ and $C_{\mathrm{p}}=-0.110+6.87 \times 10^{-4} \mathrm{~T}+6.36 \times 10^{-3} x[\mathrm{~J} /(\mathrm{g} \cdot \mathrm{K})]$, where $x$ and $T$ are the composition of $\mathrm{H}$ in $\mathrm{UTh}_{4} \mathrm{Zr}_{10} \mathrm{H}_{\mathrm{x}}$ and the temperature (Tsuchiya et al., 2000). The high thermal conductivity (approximately $0.13 \mathrm{~W} /(\mathrm{cm} \cdot \mathrm{K})$ ) for $\mathrm{UTh}_{4} \mathrm{Zr}_{10} \mathrm{H}_{\mathrm{x}}(18-27)$ at a 
temperature of $700 \mathrm{~K}$, which is close to the reported value $(0.18 \mathrm{~W} /(\mathrm{cm} \cdot \mathrm{K}))$ for $10 \mathrm{wt} \% \mathrm{U}$ $\mathrm{ZrH}_{1.6}$, increases the safety level in reactors when the linear power is high. For all the $\mathrm{UTh}_{4} \mathrm{Zr}_{10} \mathrm{H}_{\mathrm{x}}$, the temperature dependence of the thermal conductivities showed a gradual increase with increasing temperature. On the other hand, the hydrogen dependence of the thermal conductivity dramatically changed at the boundary temperature of $690 \mathrm{~K}$, corresponding to the temperature and composition dependences of the electrical property and the thermal diffusion.

The thermal conductivity was evaluated using the values of the electronic conduction, $\lambda_{e}$, obtained from the relation $\lambda_{e}=L_{e} \sigma T$, which is based on the Wiedemann-Franz rule. In this equation, $\sigma$ denotes the electrical conductivity $(\sigma=1 / \rho)$ and is obtained from the measured electrical resistivity. Further, $L_{e}$ is the Lorenz number corresponding to the electronic conduction, expressed as $L_{e}=\left(\pi^{2} / 3\right)\left(k_{B} / e\right)^{2} \approx 2.45 \times 10^{-8} \mathrm{~W} \Omega / \mathrm{K}^{2}$, where $k_{B}$ and $e$ are the Boltzmann constant and the elementary electric charge, respectively. Consequently, the thermal conductivity associated with phonon conduction, $\lambda_{p}$, was determined by subtracting $\lambda_{e}$ from $\lambda$ (i.e., $\lambda=\lambda_{e}+\lambda_{p}$ ), as shown in Figs. 6 and 7 .

For the $\mathrm{U}-\mathrm{ZrH}_{\mathrm{x}}$, heat is conducted for each phase in the temperature range $300-800 \mathrm{~K}$ because of the migration of both free electrons and phonons, although the absolute values depend on the hydrogen content and, at temperatures below $450 \mathrm{~K}$, the contribution from the phonons was greater than that from the electrons.

For $\mathrm{UTh}_{4} \mathrm{Zr}_{10} \mathrm{H}_{\mathrm{x}}$, in the temperature range $300-800 \mathrm{~K}$, the contribution of the migration of electrons to heat conduction is greater than that of the migration of phonons. The thermal property of the hydride composite materials seems to be similar to that of metals rather than insulators. It may be related to the quantity of the free electrons, derived from the heavy metals of the actinides. The reduction of the conductivity with a decrease in the hydrogen content, indicative of an increase in hydrogen vacancy, shows that phonon scattering by electrons and phonons has a significant effect on the nonstoichiometric structures of the hydrides. In particular, it is interesting that the phonon conduction increases with increasing temperature. The migration of phonons in the $\mathrm{ThZr}_{2} \mathrm{H}_{\mathrm{x}}$ phase may be enhanced at high temperatures, since the phonon conduction in the $\mathrm{Zr}_{2} \mathrm{H}_{\mathrm{x}}$ phase is usually proportional to $1 / T$, where $T$ is the temperature. The composite materials of $\mathrm{ThZr}_{2} \mathrm{H}_{\mathrm{x}}$ are now being further studied to clarify the effect of hydrogen on the thermal transportation process of the actinide-hydride materials in more detail.

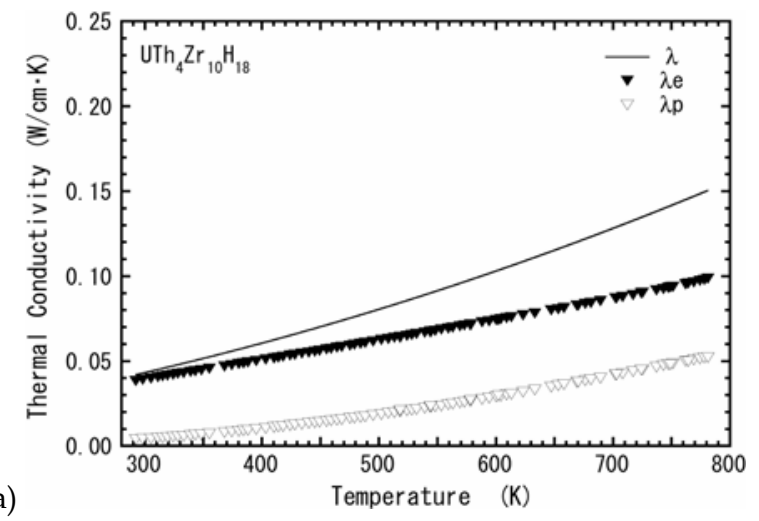




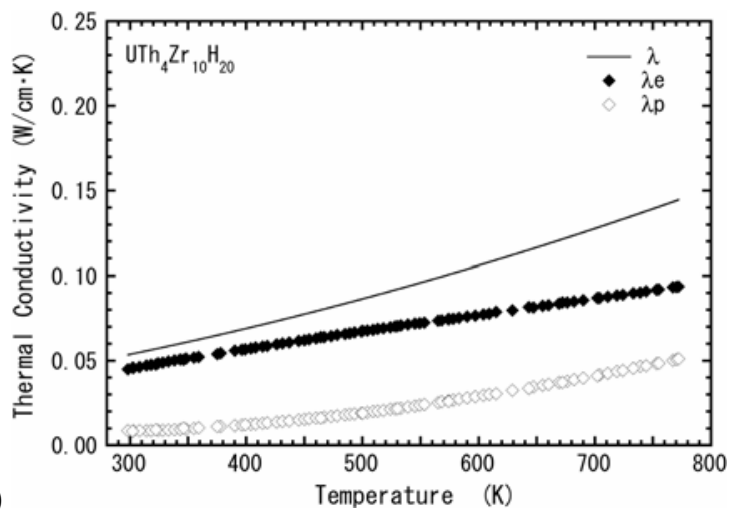

(b)

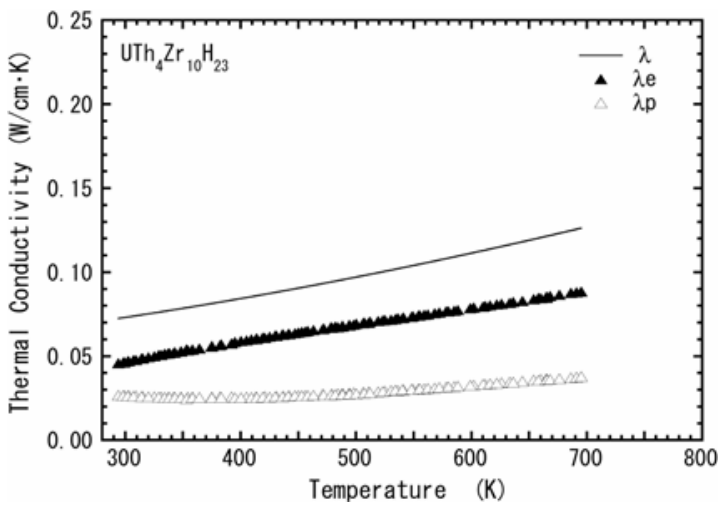

(c)

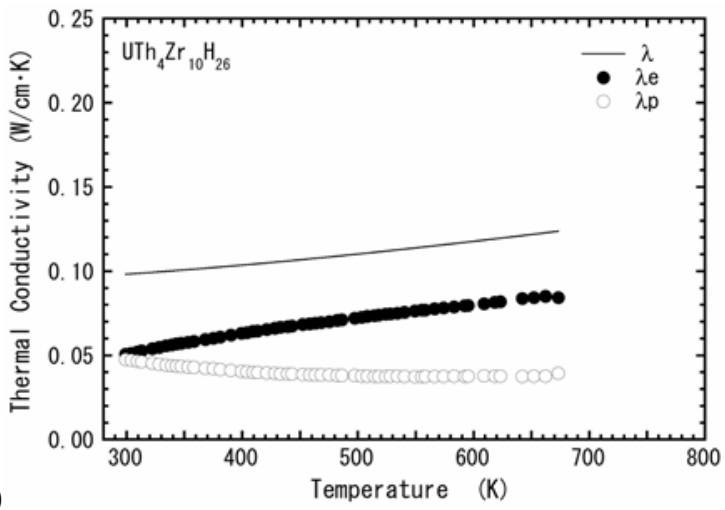

Fig. 7. Thermal conductivities, $\lambda$, of (a) $\mathrm{UTh}_{4} \mathrm{Zr}_{10} \mathrm{H}_{18}$, (b) $\mathrm{UTh}_{4} \mathrm{Zr}_{10} \mathrm{H}_{20}$, (c) $\mathrm{UTh}_{4} \mathrm{Zr}_{10} \mathrm{H}_{23}$, and (d) $\mathrm{UTh}_{4} \mathrm{Zr}_{10} \mathrm{H}_{26}$. $\lambda_{\mathrm{e}}$ and $\lambda_{\mathrm{p}}$ represent the thermal conductivity due to free electrons and that due phonons, respectively 


\section{Conclusions}

The thermal diffusivities of the actinide-hydride composite materials such as $45 \mathrm{wt} \% \mathrm{U}$ $\mathrm{ZrH}_{\mathrm{x}}\left(x=1.60\right.$ and 1.90) and $\mathrm{UTh}_{4} \mathrm{Zr}_{10} \mathrm{H}_{\mathrm{x}}(x=18-27)$ were measured by the laser flash method, and their thermal conductivities were calculated by taking into account the density and the specific heat. The thermal conductivity was significantly dependent on the quantities of doped actinide metals and formed hydrides in the composite materials and, in particular, on the hydrogen concentration. The heat conduction due to electrons and that due to phonons were determined using the Wiedemann-Franz rule on the basis of the electrical conductivity calculated using the measured electrical resistivity. In the case of thermal conduction by $\mathrm{U}-\mathrm{ZrHx}$ at room temperature, phonon-phonon scattering is dominant, and the number of electrons and photons are approximately equal in the case of heat conduction at high temperatures of above $450 \mathrm{~K}$. In addition, the thermal conductivity decreases with a decrease in the hydrogen content; this is indicative of an increase in the hydrogen vacancy, because phonon scattering by electrons and phonons has a significant effect on the nonstoichiometric structures of the hydrides.

The actinide-hydride composite materials of $\mathrm{UTh}_{4} \mathrm{Zr}_{10} \mathrm{H}_{\mathrm{x}}$ showed a gradual increase in the thermal conductivities with an increase in the temperature. The dependence of the thermal conductivities on the composition showed an increase with an increase in the hydrogen content at temperatures below approximately $690 \mathrm{~K}$. In contrast, a decrease in the composition dependence was observed at temperatures above $690 \mathrm{~K}$. For heat conduction at temperatures below $690 \mathrm{~K}$, the contribution of the migration of the electrons is considerably larger than that of the migration of the phonons. The increase in the conductivity at higher temperatures may be attributed to the enhancement of phonon conduction in the $\mathrm{ThZr}_{2} \mathrm{H}_{x}$ phase.

It is concluded that the actinide-hydride composite materials with high thermal conductivities of approximately $0.27 \mathrm{~W} /(\mathrm{cm} \cdot \mathrm{K})\left(45 \mathrm{wt} \% \mathrm{U}-\mathrm{ZrH}_{1.60}\right), 0.43 \mathrm{~W} /(\mathrm{cm} \cdot \mathrm{K})(45 \mathrm{wt} \%$ $\left.\mathrm{U}-\mathrm{ZrH}_{1.90}\right)$, and $0.13 \mathrm{~W} /(\mathrm{cm} \cdot \mathrm{K})\left(\mathrm{UTh}_{4} \mathrm{Zr}_{10} \mathrm{H}_{18-27}\right)$ at $700 \mathrm{~K}$, which have thermal properties similar to those of metals, are potential candidates for fabricating the irradiation target used in the transmutation of actinide radioactive wastes.

\section{References}

Yamamoto, T., Suwaruno, H., Kayano, H. \& Yamawaki, M. (1997). J. Nucl. Mater., 247, 339344.

Yamawaki, M., Suwarno, H., Yamamoto, T., Sanda, T., Fujimura, K., Kawashima, K. \& Konashi, K. (1998). J. Alloys Comp., 271-273, 530-533.

Konashi, K., Tsuchiya, B., Yamawaki, M., Fujimura, K. \& Sanda, T. (2001). Proceedings of International Conference on Back-End of the Fuel Cycle from Research to Solutions, GLOBAL2001, Paris, France.

Tsuchiya, B., Huang, J., Konashi, K., Teshigawara, M. \& Yamawaki, M. (2001). J. Nucl. Mater., 289, 329-333.

Huang, J., Tsuchiya, B., Konashi, K. \& Yamawaki, M. (2000). J. Nucl. Sci. Technol., 37(10), 887892.

Tsuchiya, B., Huang, J., Konashi, K., Saiki, W., Onoue, T. \& Yamawaki, M. (2000). J. Alloys Comp., 312, 104-110. 
Tsuchiya, B., Konashi, K., Yamawaki, M. \& Nakajima, Y. (2002). J. Nucl. Sci. Technol., Suppl.3, 855-857.

Nakata, M. M., Ambrose, C. J. \& Finch, R. A. (1966). Proceedings of 6th Conf. On Thermal Conductivity, pp. 479-507.

Tsuchiya, B., Teshigawara, M., Konashi, K., Nagata, S., Shikama, T. \& Yamawaki, M. (2002). J. Nucl. Sci. Technol., 39(4), 402-406.

Takahashi, Y., Yamawaki, M. \& Yamamoto, K. (1988). J. Nucl. Mater., 154, 141-144.

Bickel, P. W. \& Berlincourt T. G. (1970). Phys. Rev. B, 2(12), 4807-4813.

Bell, I. P. (1954). UKAEC, RDB(c) TN-101, 1-16.

Simnad, M. T. (1981). Nucl. Eng. Des., 64, 403-422. 


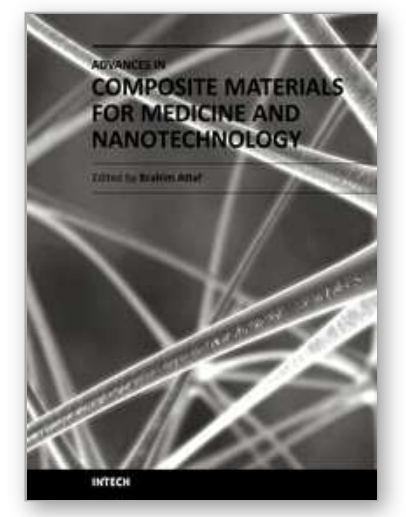

\section{Advances in Composite Materials for Medicine and Nanotechnology}

Edited by Dr. Brahim Attaf

ISBN 978-953-307-235-7

Hard cover, 648 pages

Publisher InTech

Published online 01, April, 2011

Published in print edition April, 2011

Due to their good mechanical characteristics in terms of stiffness and strength coupled with mass-saving advantage and other attractive physico-chemical properties, composite materials are successfully used in medicine and nanotechnology fields. To this end, the chapters composing the book have been divided into the following sections: medicine, dental and pharmaceutical applications; nanocomposites for energy efficiency; characterization and fabrication, all of which provide an invaluable overview of this fascinating subject area. The book presents, in addition, some studies carried out in orthopedic and stomatological applications and others aiming to design and produce new devices using the latest advances in nanotechnology. This wide variety of theoretical, numerical and experimental results can help specialists involved in these disciplines to enhance competitiveness and innovation.

\section{How to reference}

In order to correctly reference this scholarly work, feel free to copy and paste the following:

B. Tsuchiya, K. Konashi and M. Yamawaki (2011). Dependence of Thermal and Electrical Conductivities of Actinide-Zirconium-Hydride Composite Materials on Hydrogen Concentration, Advances in Composite Materials for Medicine and Nanotechnology, Dr. Brahim Attaf (Ed.), ISBN: 978-953-307-235-7, InTech, Available from: http://www.intechopen.com/books/advances-in-composite-materials-for-medicine-andnanotechnology/dependence-of-thermal-and-electrical-conductivities-of-actinide-zirconium-hydride-compositematerial

\section{INTECH}

open science | open minds

\section{InTech Europe}

University Campus STeP Ri

Slavka Krautzeka 83/A

51000 Rijeka, Croatia

Phone: +385 (51) 770447

Fax: +385 (51) 686166

www.intechopen.com

\section{InTech China}

Unit 405, Office Block, Hotel Equatorial Shanghai

No.65, Yan An Road (West), Shanghai, 200040, China

中国上海市延安西路65号上海国际贵都大饭店办公楼405单元

Phone: +86-21-62489820

Fax: $+86-21-62489821$ 
(C) 2011 The Author(s). Licensee IntechOpen. This chapter is distributed under the terms of the Creative Commons Attribution-NonCommercialShareAlike-3.0 License, which permits use, distribution and reproduction for non-commercial purposes, provided the original is properly cited and derivative works building on this content are distributed under the same license. 